\title{
Recent Advances in the Study of Hepatocellular Carcinoma
}

\author{
Hidetsugu Saito and Masaharu Tsuchiya \\ Department of Internal Medicine, School of Medicine, Keio University, Tokyo, Japan
}

(Received for publication on April 17, 1992)

\begin{abstract}
Among the known causes for the occurrence of hepatocellular carcinoma (HCC), chemical carcinogens, chronic alcoholic intake and hepatitis B virus ( $\mathrm{HBV})$, especially in Asia, has been emphasized. $\mathrm{HBV}$ has been industriously studied and many queries about the relationship between $\mathrm{HBV}$ infection and hepatocarcinogenesis have been clarified. Recent descovery of hepatitis $\mathrm{C}$ virus $(\mathrm{HCV})$ revealed that there may be the participation of this virus in hepatocarcinogenesis. However, a precise mechanism in such a viral infection has not been known. Host immunological defence mechanisms including the role of cytokines should be also taken into consideration. Cellular gene abnormalities have been noted in the late period of cancer cell progression. The technical development in the clinically available diagnostic procedures have enabled us to detect early phase of HCC. Some new concepts in the pathological diagnosis of precancerous lesions of HCC and also early HCC have been reported recently. We gave an outline of the recent advances and references in the study of HCC. (Keio J Med 41 (4): 195-204, December 1992)
\end{abstract}

Key words: hepatitis $B$ virus, hepatitis $C$ virus, immunological defence mechanism, early detection

\section{Introduction}

It has been regarded that major hepatocarcinogens are some chemical agents, ${ }^{1-3}$ chronic alcoholic intake ${ }^{4}$ and hepatitis B virus (HBV). Recent studies have suggested that hepatitis $\mathrm{C}$ virus $(\mathrm{HCV})$ can likewise be regarded as one of carcinogen. For several years, we have been studying the host's immunological abnormalities as noted in chronic liver diseases; a significant decrease in host defense mechanisms could be considered as one important factor for the progression of liver cirrhosis (LC) into hepatocellular carcinoma (HCC). There may be other unknown causes for the occurrence of HCC which remains to be explored.

\section{Hepatitis B Virus (HBV)}

It is well known from epidemiological studies, ${ }^{5-7}$ that there is a correlation between the occurrence of $\mathrm{HCC}$ and HBV infection. Since such a significant finding has been discovered, the study of HBV has been emphasized and a lot of important dicoveries have been made regarding this special area of cancer research. ${ }^{8,9} \mathrm{HBV}$ has been very well investigated. ${ }^{10}$ Its DNA sequences have been completely studied. ${ }^{11}$ The proteins produced by this virus are encoded in specific DNA regions (Fig 1); eg, hepatitis B surface antigen (HBsAg), hepatitis B core antigen ( $\mathrm{HBcAg}$ ), and DNA polymerase (DNA-p) which are some of the proteins produced by this virus, are encoded in their respective regions in the HBV DNA loci. Moreover, special attention should be focused on the fact that although oncoviruses, which are usually retroviruses, have their oncogenes included in their genomes, this phenomenon does not hold true for HBV genome, then another interesting feature of $\mathrm{HBV}$ which remains to be explained. HBV has interesting replication strategies. ${ }^{12}$ As shown in Fig 2, the HBV DNA is transcribed into RNA and translated into specific proteins. On the other hand, during replication of this virus, HBV DNA is reversely transcribed ${ }^{13.14}$ into minus strand DNA and the plus strand DNA reproduced and finally the replication is completed. This complicated way of replication brings about an important change in the hepatocytes infected with $\mathrm{HBV}$; that is, HBV DNA integration. Our results ${ }^{15}$ showed that HBV DNA was integrated in all of the $8 \mathrm{HCC}$ tissues from $\mathrm{HBsAg}$ positive patients examined by Southern blot analysis. Okubo et al $^{16}$ demonstrated that HBV DNA integration 


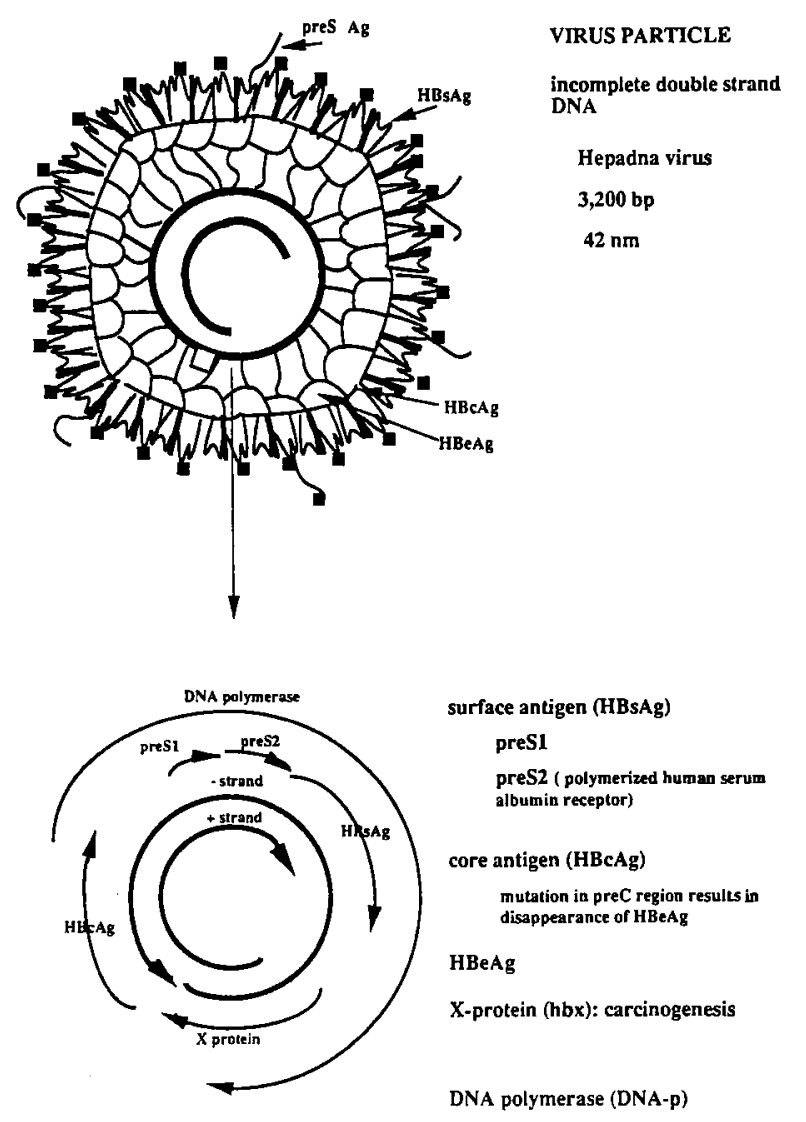

Fig 1 The schematized construction of the hepatitis B virus. The relationship between the genomic structure and viral antigens is explained.

occurred only 2 or 3 days after the viral infection to human primary hepatocyte culture. However, the DNA binding pattern was so different from each other. This finding was supportive of the claim that there is no specific HBV DNA integration pattern in the development of $\mathrm{HCC} .{ }^{17}$ It is important that the integration is associated with insertion and deletion formation and is often associated with host chromosomal rearrangements. ${ }^{18,19}$ Moreover, some of the integrated viral genomes exert transactivation of the host genes. ${ }^{20,21}$ Even these results suggested that $\mathrm{HBV}$ is a oncogenic virus.

Turning on the possibility of $\mathrm{HCC}$ as being multicentric, ${ }^{22}$ DNA from various lesions from a HCC patient were analyzed by Southern blotting. Interestingly enough, some of $\mathrm{HBV}$ DNA integration patterns were found to be different, supporting then the claim of multicentricity of $\mathrm{HCC} .{ }^{23} \mathrm{We}$ also experienced a case whose $\mathrm{HBV}$ DNA integration patterns in tissue DNA were different between a main tumor and a metastasized lymph node. ${ }^{15}$ There is a great possibility that after a solitary HCC has been surgically removed, tumors in other regions have

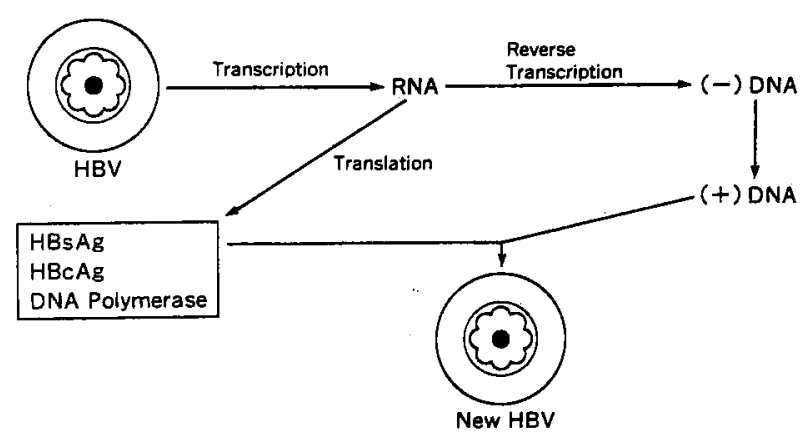

Fig 2 Replication strategies of the HBV.

a great propensity to develop, eg, postoperatively, if indeed another tumor develops, we cannot definitely say if it is a metastasis or a primary tumor in itself.

Many reports have been focused and accumulated about HBV X-protein. Recent studies have shown that $\mathrm{X}$-protein ${ }^{10}(\mathrm{hbx})$ which is drawn from $\mathrm{X}$ gene of HBV DNA promotes hepatocarcinogenesis. It has been demonstrated that this protein has a transactivating activity $^{24}$ of enhancing the genes in hepatocyte DNA including HBV genome itself, the SV40 promotor and enhancer, long terminal repeat (LTR) of human immunodeficiency virus (HIV), Rous sarcoma virus (RSV), human $\mathrm{T}$ cell leukemia virus I (HTLV-I), $\beta$-interferon gene, c-fos, c-myc and RNA-polymerase II and III promotors. ${ }^{25-29}$ Each gene is specifically activated according to the type of cells. However, hbx can not directly combine with DNA itself. It is most possible that hbx transactivates various genes by the interaction through some hbx responsive element binding factors. ${ }^{30-34}$ There are reports that hbx has a protein kinase activity ${ }^{35}$ or a serine protease inhibitor activity. ${ }^{36}$ Kim et al have revealed that the transgenic mice transfected with a part of HBV DNA including $X$ gene, in which hbx was excessively produced in the liver, soon (8-10 months later) developed HCC. ${ }^{37}$ However, there are reports which disclaim the direct correlation between HBV DNA integration and hepatocarginogenesis ${ }^{38,39}$ even in transgenic mice. ${ }^{40}$ Chisari et al ${ }^{41-43}$ made the transgenic mice in which large envelope polypeptides of HBV was produced excessively. In these mice, hepatic necrosis, inflammation and regeneration were observed in the liver and at last $\mathrm{HCC}$ appeared after about 1 or 2 years. This model is compatible to the development of human $\mathrm{HCC}$ which always accompanied with chronic liver diseases. In chronic liver diseases, there continues inflammation and the recurrence of necrosis and regeneration. Some minor stimulations like oxidants 44,45 may result in the occurrence of $\mathrm{HCC}$ through this recurrence. Thus, it is strongly suggestive that $\mathrm{HBV}$ is a hepatocarcinogenic virus. Many reports have been 
accumulating which are interesting enough to understand HBV biology. ${ }^{17,46-49}$

\section{Hepatitis C Virus (HCV)}

Since the discovery of a part of hepatitis $C$ virus (HCV) genome, ${ }^{50}$ the development of the study in $\mathrm{HCV}$ biology is so rapidly performed. On the other hand, the direct demonstration of its hepatocarcinogeneity has not been reported yet. We established a human hepatoma cell line HCC-T from a nonA nonB (NANB) hepatoma patient $^{51}$ and it was demonstrated that he had been infected with HCV though there was no HCV RNA nor DNA in this cell line detected by RT-PCR technique. It is obvious that in patients afflicted with $\mathrm{HCC}$, positive rate for their serum $\mathrm{HCV}$ antibodies are high. ${ }^{52-61}$ Although positivity of serum $\mathrm{HCV}$ antibody in children below 15 years old was reported to be very low in $1990^{62}$ and this led us to speculate that there is no vertical transmission of HCV, Thaler et $a l^{63}$ and Kuroki et $a l^{64}$ reported the possibility of the vertical transmission in 1991. This should stimulate further inquiry or studies ${ }^{65}$ to clarify the relationship between $\mathrm{HCV}$ and hepatocarcinogenesis as studied in HBV. Now it has been demonstrated that HCV genome (HCV-J) derived from a Japanese NANB hepatitis patient is composed with apparently different nucleotide sequence from that reported by Chiron group (HCV-US) by using RT-PCR method. ${ }^{66-68}$ Other types of HCV (K2, group II) whose nucleotide sequence showing less identical with that of HCV-US were also reported. ${ }^{69,70}$ Kato et al ${ }^{71}$ determined the entire nucleotide sequence of $\mathrm{HCV}-\mathrm{J}$ genome. Takamizawa $e t a l^{72}$ determined that of one type (HCV$\mathrm{BK})$. US-type $\mathrm{HCV}$ genome was also analyzed and it became to be possible to postulate genomic products. $\mathrm{HCV}$ genome contains a long open reading frame encoding a protein of 3010 amino acid residues. The genomic analyses and comparative study with the pestivirus have shown that HCV proteins encoded by the extreme 5' region are (1) capsid protein (p22); (2) envelop protein (gp 35, gp 70); followed by non-structural proteins (NS1-5) which may be necessary for viral replication. The sequence diversity has been found among the virus isolates with about $10 \%$ in nucleotide sequence and $5 \%$ in amino acid sequence and two hypervariable regions in the envelope region. ${ }^{73,74}$ Now, HCV genotype was categolized into 4 groups. ${ }^{75}$ The genomes isolated from USA (HCV-H, HCT 18, 23, 27; Th; ECl, 10), Germany (GM2), France (HCVE1) and England are homologous to type I. The genomes isolated from Japan, Taiwan (HCV-T3) and China are homologous to type II. HC-J5, HC-J6 and HCV-K2a are categolized into type III. HC-J6, J7; HCV-K2b, clone A are categolized into type IV. The conserved region of the HCV genome in all isolates is found at the extreme 5' end, capsid region and
NS4 region of the genome. These 3 regions are most useful regions for diagnosis of the HCV genome or the detection of antibodies.

As we mentioned before, there are possibility of the $\mathrm{HCV}$ as a carcinogen. The first possibility is the existance of oncogenic gene in the HCV genome. The second is the integration of the $\mathrm{HCV}$ genome into the host genome as observed in the HBV biology. The third is that gene products like hbx activate the cellular gene transcription. As HCV is considered to belong to a new genus distinct from the Flaviviridae, which is categolized into RNA virus not retrovirus, the first and second possibilities can be neglected. The third possibility should be further studied. But we believe necrosis and regeneration of the hepatocytes in chronic liver diseases may be more important cause of the hepatocarcinogenesis.

\section{Host Immunological Defence Status}

We have demonstrated that the host's immnological defense status in patients with LC decreases compared with that of healthy control. ${ }^{76} \mathrm{NK}$ activity decreases in patients with $\mathrm{LC} .{ }^{77.78}$ It has been noted that many $\mathrm{HCC}$ developed in patients with $\mathrm{LC},{ }^{79}$ leading us to conclude that NK activity is one of the factors which can explain the development of HCC in LC. Similar aspects have been reported by others. ${ }^{80.81}$ We examined the relationship between NK activity and the resistance against the graft challenge of a human HCC cell line in nude mice. ${ }^{82}$ Those studies suggested that nonspecific cytotoxic cells play crucial roles in the resistance against tumor cell challenge and that the total level of cytotoxic activity of these cells at the time of tumor cell challenge is a key factor which determines tumor development. We further examined the role of neutrophils in the early phase of tumor elimination. ${ }^{83}$ It is suggested that the oxidative stress plays an important role in neutrophil-mediated cytotoxicity. Shimizu et $a l^{84}$ analyzed tumor infiltrating lymphocyte (TIL) from primary and metastatic hepatic tumor and reported that most TIL were activated T lymphocytes. TIL from primary tumor had a stronger activity to kill auto-tumor cells than those from metastatic tumor. Among the sinusoidal cells, especially Kupffer cell function should be also taken into consideration in the elimination of metastatic tumor cells. ${ }^{85}$ Recent our study demonstrated that nitric oxide is a key factor in Kupffer cell-mediated cytotoxicity (paper in submitted).

\section{Transforming Growth Factor- $\beta$ (TGF- $\beta$ )}

TGF- $\beta$ has been studied in the field of regulation of hepatic fibrogenesis by Kupffer cells. ${ }^{86,87}$ Besides that, Ito $e t a l^{88}$ reported increased level of TGF- $\beta$ mRNA trasncription in resected $\mathrm{HCC}$ tissues. Although TGF- $\beta 1$ is known to inhibit the proliferation of hepatocytes, 
the proliferation of HCC cells can not be inhibited, suggesting that $\mathrm{HCC}$ cells lose the sensitivity against TGF- $\beta 1 .^{89}$

\section{Oncogenes and Chromosome Abnormalities}

We transfected the cellular DNA of a human hepatoma cell line $\mathrm{HCC}-\mathrm{M}^{90}$ into a murine fibroblast cell line NIH/3T3 and found that both HBV DNA with a human repetitive sequences integrated into NIH/3T3 cells. ${ }^{91}$ This suggested that transformation occurred as the result of the transfer of proto-oncogene which might be closely associated with HBV genome. However, it was then demonstrated that there was no specific proto-oncogene expressions nor ras gene mutations in 3 human hepatoma cell lines including HCC-M. ${ }^{17}$ Tada et a $l^{92}$ also reported that there is a scarce correlation between ras mutation and hepatocarcinogenesis. On the other hand, Ogata et $a l^{93}$ and Richards et $a l^{94}$ reported that ras mutation was important event in hepatocarcinogenesis in $\mathrm{HCC}$ tissues and a cell line. Many reports suggested that no sepecific oncogene expression is responsible to hepatocarcinogenesis. Tumor suppressor gene was also focused about $\mathrm{HCC}$ development in recent years. ${ }^{93,95-100}$ One of such genes, p53 is known to be located in chromosome $17 \mathrm{p}$ and to code one of nuclear phospholiration protein which negatively regulate a cell cycle. It was reported that a half of $\mathrm{HCC}$ cases have a mutation of this gene in China ${ }^{101}$ and south Africa. ${ }^{102}$ while they might be related to chemically occurred $\mathrm{HCC}$ with afratoxin. Abnormalities in chromosome $1,{ }^{103}$ and deletion of chromosomes $4,{ }^{95-97,104} 5,{ }^{97} 8,,^{96,97} 10,,^{97} 11,{ }^{96,97}$ $13,96,9716,96,97,100,104$ and $17^{96,97}$ have been reported. However, these chromosomal changes are suggested to be the events which occur at the late progressive period of cancer cells. There remains unclear what the initial event of malignant transformation in the hepatocyte is.

\section{Early Detection of $\mathrm{HCC}$}

Cellular changes occur in the hepatocyte and after the clonal proliferation of the abnormal hepatocytes resulting into a hepatic malignant tumor, which should be clinically detected. It is said that it takes about 20 years from the occurrence of a cancer cell until when we can detect a tumor clinically. A careful detection of hepatic malignant tumors must be done particularly in patients with LC as well as with the HBsAg-positive carriers, since these are conditions which are thought to be highly predisposed to the occurrence of HCC. As it is well known, these clinically available examinations are ultrasonography, ${ }^{105}$ CT-scan, ${ }^{106}$ MRI, ${ }^{107,108}$ tumor markers ${ }^{109-115}$ and liver chemistries. The development of the techniques for a needle biopsy under ultrasonography and the relative pathological study between biopsy samples and surgically resected tissues enabled us to characterize pathological features of early small hepatic tumors. ${ }^{116-120}$

After initial detection of the hepatic tumor, a hepatic angiography is recommended to make sure whether a tumor is definitely malignant or not. Moreover, it was only until a few years ago, when angiography has been selected as the best procedure to further define hepatic tumors. However, recently a small hepatic tumor which is under one or two $\mathrm{cm}$ in diameter can always be detected by ultrasonography. Such a small tumor cannot easily be detected by CT-scan nor angiography, since most of the time it results into a negative study.

Pathological examinations of these small tumors revealed that the preexisting liver structure was preserved. All of these cases were hypercellular lesions and it has been suggested by some pathologists that these small hepatic tumors can be classified into three categories, namely; adenomatous hyperplasia, which lacked structural atypia; atypical adenomatous hyperplasia with nodules exhibiting focal abnormalities; and finally, the very differentiated $\mathrm{HCC}$ with little cellular atypia. From these examinations, ${ }^{121-123}$ it has been thought that there is a multistep development of HCC. One of them is adenomatous hyperplasia which might be a precancerous lesion of $\mathrm{HCC}^{124}$.

Figure 3 shows a series of ultrasonograms and CTscan photoes, all belonging to one patient of ours, who had been examined during a year and a half, that is, from the 13th of February, 1990 up to 1st of August, 1991 (dates: 13/2/90, 10/9/90, 14/1/90, 5/3/91, 1/8/91). The lower photographs are CT-scan photos taken during the first and last date. From here, we could see that we could not distinguish the characteristics of the tumor just by the CT-scan with ordinal use. However, these could be notably distinguished by the ultrasonograms. The median photograph shows the presence of a low density area or hypoechoic region which can detected in the high density area or high echoic region. And then, the low echoic region spreads diffusely into the high echoic area. Figure 4 shows the schematic representation of such a phenomenon. That is, a small hypoechoic region is first detected, which then develops into the hyperechoic area, gradually diffusing or spreading out till it occupies the whole region. This superimposed low-high echoic area, gradually grows larger and larger. It is interesting to note here, that when biopsy samples are taken from these regions, that sample taken from the hyper-echoic region will show fatty changes. ${ }^{125}$ Meanwhile, in the hypohyperechoic area, adenomatous hyperplasia can be descovered. However, in some cases, early stages of $\mathrm{HCC}$, and likewise, its undifferentiated stage, may even be seen.

A possible explanation could account for such a phenomenon; that is, during the development of the 


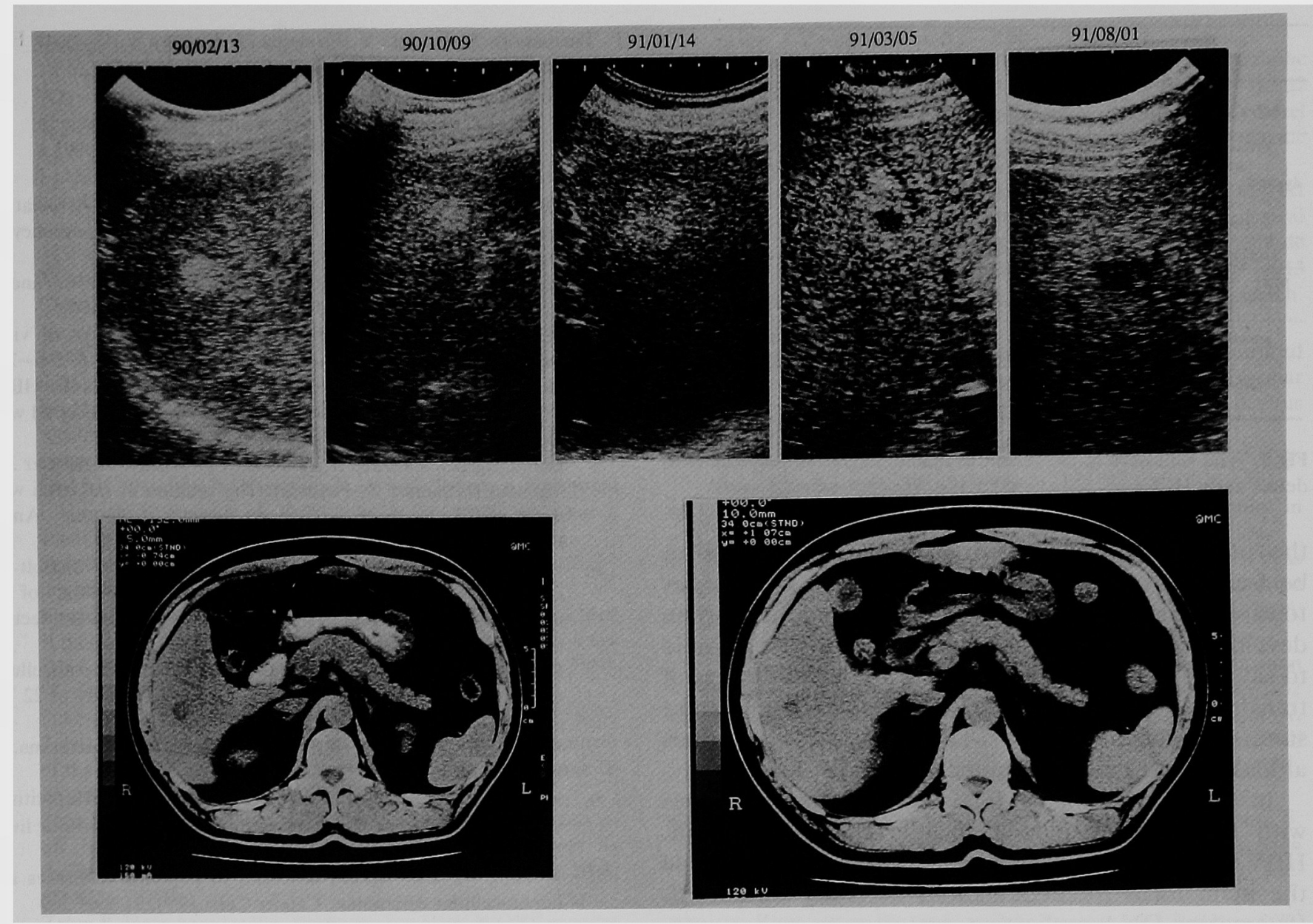

Fig 3 The development of early HCC detected by the ultrasonography. A series of photographs in one patient from February 13th, 1990 to August 1st, 1991.

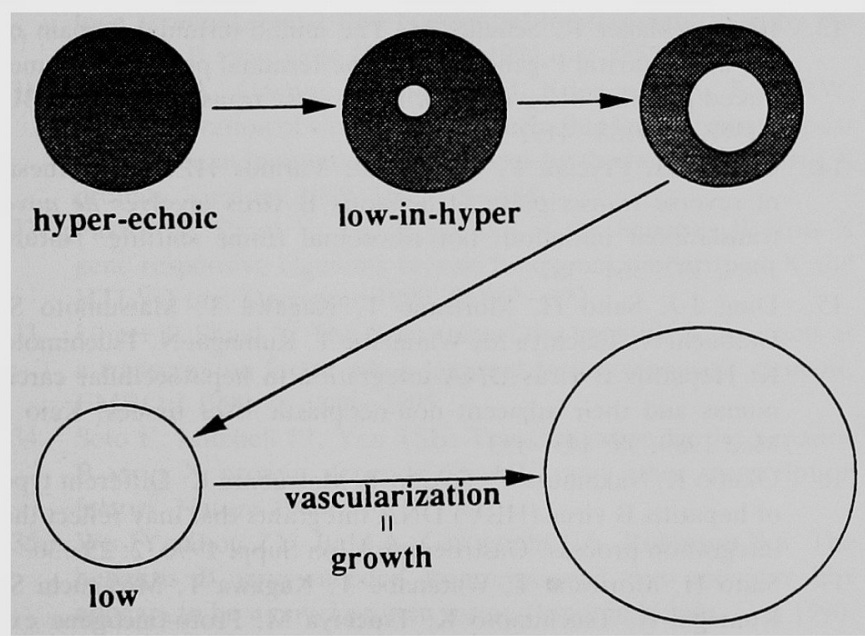

Fig 4 The schematic changes in the photographs of ultrasonography during the development of early HCC.

hypo-echoic area, vascularization may occur in the tumor itself and nutrition is being given, promoting the further growth of this tumor. ${ }^{126}$ Thus, before this vascularization period, hepatic angiography of this tumor may result into a negative study. ${ }^{127-129}$ During pre-vascularization period, the tumor may be nourished via the blood supply coming from the portal vein. Thereafter, the tumor's post-vascularization nutrition may come from the hepatic artery. During such stage, the HCC cells undergo a significant change from an early stage to an undifferentiated state.

A summary of the recent diagnostic procedures about HCC is shown on Figure 5. The CT during arterial portography (CTAP, portal CT-scan), ${ }^{130}$ in which perfusion of the contrast medium from the superior mesenteric artery is done, is useful in detecting early HCC. ${ }^{131-133}$ By using this procedure, we can distinguish significantly the tumor into which nutrition is being supplied through the portal circulation from through the hepatic artery. Lipiodol computed tomography is also reccommended to evaluate small HCC. ${ }^{134}$

It is well known that mature hepatocytes produce albumin, while the fetal counterparts produce $\alpha$-fetoprotein (AFP). Since some hepatoma cells can produce AFP, 


\begin{tabular}{|c|c|c|c|}
\hline & $\begin{array}{l}\text { adenomatous } \\
\text { hyperplasia (AH) }\end{array}$ & early cancer & cancer \\
\hline Ultra Sound & $\begin{array}{l}\text { hyper (fatt) } \\
\rightarrow \text { iso wypo }\end{array}$ & iso $\sim$ hypo & hypo \\
\hline $\begin{array}{c}\text { CT scan } \\
\text { simpie } \\
\text { dynamic early phase } \\
\text { late phase } \\
\text { enhance }\end{array}$ & $\begin{array}{l}\text { iso }- \text { low } \\
\text { iso } ~-~ l o w \\
\text { iso }- \text { low } \\
\text { iso - low }\end{array}$ & $\begin{array}{c}\text { iso }- \text { low } \\
\text { slight high } \text { iso } \\
\text { low }- \text { iso } \\
\text { iso }- \text { low }\end{array}$ & $\begin{array}{l}\text { low } \\
\text { high } \\
\text { low } \\
\text { low }\end{array}$ \\
\hline angiography & hypo & iso - slightly hyper & hyper \\
\hline $\begin{array}{cc}\text { MRI T1-enhance } \\
\text { T2-enhance }\end{array}$ & $\begin{array}{l}\text { iso high (low) } \\
\text { iso-high }\end{array}$ & $\begin{array}{c}\text { iso- high (low) } \\
\text { iso-high }\end{array}$ & $\begin{array}{l}\text { low } \\
\text { high }\end{array}$ \\
\hline portal Cr & entance & perfusion defect & defect \\
\hline nuitrition & Ponal & anerior & \\
\hline
\end{tabular}

Fig 5 The summary of the recent available diagnostic procedures to detect early HCC.

the process of malignant transformation suggests to be frequently associated with a change in hepatocytes towards the immature state. This corresponds to a certain developmental stage of the fetus. Therefore, it is possible to say that hepatocarcinogenesis is a gradual process of transfromation into the undifferentiated or immature state of the hepatocyte. ${ }^{135}$ The similar discussion has already been carried out in leukemic cells.

In summary, we have discussed the important issues with regards to hepatocarcinogenesis. Among them, $\mathrm{HBV}$ is the most significant factor which continues to be the main focus of investigations currently conducted. Its amazing DNA replication strategies, as well as integration into the host's DNA have indeed made the HBV DNA study more challenging than ever to any investigator. Chronic inflammation of the liver may play some important role in the occurrence of malignant transformation in the hepatocyte. Although the direct demonstration of $\mathrm{HCV}$ as a hepatocarcinogenesis has not been reported, recent interferon therapy against chronic hepatitis $\mathrm{B}$ and $\mathrm{C}$ might achieve in future the decrease in number of HCC occurrence. ${ }^{136}$ Many investigators, as well as our group, have been continuously involved in conducting studies which will unfold to us more of the mysteries behind HCC, and many clinicians have been trying to detect the HCC earlier and treat the patients better.

Acknowledgment: A part of this article was presented by Saito $\mathrm{H}$ in the Annual Convention of the Philippinc Society of Oncologists as a State-of-the-Art lecture held on November 23, 1991 at the Philippine Plaza Hotel. We would like to thank Drs Toshiharu Tsuzuki (Department of Surgery), Kyoichi Hiramatsu (Department of Diagnostic Radiology), Hiromasa Ishii (Department of Internal Medicine), Masakazu Ueda (Department of Surgery), Yoshiaki Narimatsu (Department of Radiology) and Shigeru Kuramochi (Department of Pathology) who are counsilors of the Study Group of Hepatic Tumors in Keio University Hospital, and Drs Hashimoto $S$ and Nakatsuka $S$ (Department of Diagnostic Radiology) for their generous suggestions, discussions and helps. Authors also thank Dr Morizane T, Watanabe
T, Tsuchimoto K, Inagaki Y, Kumagai N, Kagawa T, Guevara FM, Miyaguchi $\mathbf{S}$, Tsunematsu $\mathrm{S}$ and Tada $\mathrm{S}$ for their helps.

\section{References}

1. Alpert MF, Hutt MS, Wogan GN, Davidson CS: Association between aflatoxin content of food and hepatoma frequency in Uganda. Cancer 1971, 28: 253-260

2. Peers FG, Linsell CA: Dietary aflatoxin and human liver cancer. A study in Swaziland. Int J Cancer 1976, 17: 167-176

3. Maltoni $C$, Lefemine $G$ : Carcinogenicity bioassays of vinyl chloride: current results. Ann NY Acad Sci 1975, 246: 195-218

4. Horiike N, Michitaka K, Onji M, Murota T, Ohta Y: HBVDNA hybridization in hepatocellular carcinoma associated with alcohol in Japan. J Med Virol 1989, 28: 189-192

5. Blumberg BS, Larouze B, London WT, Werner B, Hesser JE, Millman P, Saimot G, Payet M: The relation of infection with the hepatitis $B$ agent to primary hepatic carcinoma. Am J Pathol 1975, 81: 669-682

6. Prince AM, Szmuness W, Michon J, Bemaille J, Biebolt G, Linhard J, Quenum C, Sankale M: A case control study of the association between primay liver cancer and hepatitis $B$ infection in Senegal. Int J Cancer 1975, 16: 376-383

7. Beasley RP, Hwang LY, Lin CC, Chien CS: Hepatocellular carcinoma and hepatitis B virus. A prospective study of 22707 men in Taiwan. Lancet 1981, 2: 1129-1133

8. Wands JR, Blum HE: Primary hepatocellular carcinoma. N Engl J Med 1991, 325: 729-731

9. Kalayci C, Johnson PJ, Davies SE, Williams R: Hepatitis B virus related hepatocellular carcinoma in the non-cirrhotic liver. J Hepatol 1991, 12: 54-59

10. Meeting Review: Recent advances in hepatitis B viruses and hepatocellular carcinoma. Cancer Cells 1990, 2: 366-369

11. Ganam D, Varmus HE: The molecular biology of the hepatitis B viruses. Annu Rev Biochem 1987, 56: 651-693

12. Will H, Reiser W, Weimer T, Pfaff E, Busher M, Sprengel R, Cattaneo R, Schaller H: Replication strategy of human hepatitis B virus. J Virol 1987, 61: 904-911

13. Bartenschlager $\mathrm{R}$, Schaller $\mathrm{H}$ : The amino-terminal domain of the hepadnaviral P-gene encodes the terminal protein (genomelinked protein) believed to prime reverse transcription. EMBO J 1988, 7: 4185-4192

14. Chang LJ, Pryciak P, Ganem D, Varmus HE: Biosynthesis of reverse transcriptase of hepatitis $\mathrm{B}$ virus involves de novo translational initiation, not ribosomal frame shifting. Nature 1989, 337: 364-367

15. Ding J-J, Saito H, Morizane T, Kagawa T, Matsumoto S, Iwabuchi N, Tsuchiya M, Watanabe T, Kumagai N, Tsuchimoto $\mathrm{K}$ : Hepatitis B virus DNA integration in hepatocellular carcinomas and their adjacent non-neoplastic liver tissues. Keio J Med 1989, 38: 443-453

16. Okubo K, Nakamura T, Tokino T, Matsubara K: Different type of hepatitis B virus (HBV) DNA integrants that may reflect the integration process. Gastroenterol Jpn Suppl 1990, 2: 23-30

17. Saito $H$, Morizane $T$, Watanabe $T$, Kagawa $T$, Miyaguchi $S$, Kumagai N, Tsuchimoto $K$, Tsuchiya M: Proto-oncogene expression in three human hepatoma cell lines HCC-M, HCC-T and PLC/PRF/5. Keio J Med 1991, 40: 139-145

18. Nagaya $T$, Nakamura $T$, Tokino $T$, Tsurimoto $T$, Imai $M$ : The mode of hepatitis virus DNA integration in chromosome of human hepatocellular carcinoma. Genes Dev 1987, 1: 773-782

19. Takada S, Gotoh Y, Hayashi S, Yoshida M, Koike K: Structural rearrangement of integrated hepatitis B virus DNA as well as cellular fianking DNA is present in chronically infected hepatic 
tissues. J Virol 1990, 64: 822-828

20. Höhne M, Schaefer S, Seifer M, Feitelson MA, Paul D, Gerlich WH: Malignant transformation of immortalized transgenic hepatocytes after transfection with hepatitis $B$ virus. EMBO J 1990, 9: 1137-1145

21. Kekule AS, Lauer U, Hofschneider PH, Meyer M, Koshy R, Caselmann WH: The preSS/S region of integrated hepatitis B virus DNA encodes a transcriptional transactivator. Nature 1990, 343: $457-461$

22. Tsuda H, Hirohashi S, Shimosato $\mathbf{Y}$, Terada $\mathbf{M}$, Hasegawa $\mathbf{H}$ : Clonal origin of atypical adenomatous hyperplasia of the liver and clonal identity with hepatocellular carcinoma. Gatroenterology 1988, 95: 1664-1666

23. Sakamoto $M$, Hirohashi S, Tsuda H, Shimosato $Y$, Makuuchi M, Hosoda Y: Multicentric independent development of hepatocellular carcinoma revealed by analysis of hepatitis B virus integration pattern. Am J Surg Pathol 1989, 13: 1064-1067

24. Koike K, Shirakata Y, Yaginuma K, Arii M, Takada S, Nakamura I, Hayashi Y, Kawada M, Kobayashi M: Oncogenic potential of hepatitis B virus. Mol Biol Med 1989, 6: 151-160

25. Spandaw DF, Lee $\mathrm{CH}$ : Trans-activation of viral enhancers by hepatitis B virus X protein. J Virol 1988, 62: 427-434

26. Takada S, Koike K: Trans-activation function of a 3'-truncated $\mathrm{X}$ gene-cell fusion product from integrated hepatitis $\mathrm{B}$ virus DNA in chronic hepatitis tissues. Proc Natl Acad Sci USA 1990. 87: $5628-5632$

27. Siddiqui A, Gaynor R, Srinivasan A, Mapoles J, Farr RW: Trans-activation of viral enhancers including long terminal repeat of the human immunodeficiency virus by the hepatitis $B$ virus $X$ protein. Virology 1989, 169: 479-484

28. Seto E, Yen TSB, Peterlin BM, Ou J-H: Trans-activation of the human immunodeficiency virus long terminal repeat by the hepatitis B virus X protein. Proc Natl Acad Sci USA 1988. 85: $8286-8290$

29. Zahm P, Hofschneider PH, Koshy R: The HBV X-ORF encodes a transactivator: a potential factor in viral hepatocarcinogenesis. Oncogene 1988, 3: 169-177

30. Twu J-S Rosen CA. Haseltine WA, Robinson WS: Identificaion of a region within the human immunodeficiency virus type 1 long terminal repeat that is essential for transactivation by the hepatitis B virus gene X. J Virol 1989, 63: 2857-2869

31. Siddiqui A, Gaynor R, Mapoles J, Srinivasan A, Farr RW: Trans-activation of viral enhancers including long terminal repeat of the human immunodeficiency virus by the hepatitis $B$ virus $X$ protein. Virology 1989, 169: 479-484

32. Faktor $O$, Shaul $Y$ : The $X$ protein of the hepatitis $B$ virus $X$ gene responsive elements reveals functional similarity of $X$ and HTLV-I tax. Oncogene 1990, 5: 867-872

33. Unger $T$, Shaul $Y$ : The $X$ protein of the hepatitis $B$ virus acts as a transcription factor when targeted to its responsive element. EMBO J 1990, 9: 1889-1895

34. Seto E, Mitchell PJ, Yen TSB: Transactivation by the hepatitis $B$ virus $X$ protein depends on AP-2 and other transcription factors. Nature 1990, 344: 72-74

35. Wu JY, Zhou ZY, Judd A, Cartwright CA, Robinson WS: The hepatitis B virus-encoded transcriptional trans-activator hbx appears to be a novel protein serine/threonin kinase. Cell 1990 , 63: $687-695$

36. Takada S, Koike K: X protein of hepatitis B virus resembles a serine protease inhibitor. Jpn J Cancer Res 1990, 81: 1191-1194

37. Kim CM, Koike K, Saito I, Miyamura T, Jay G: HBx gene of hepatitis $\mathrm{B}$ virus induces liver cancer in transgenic mice. Nature 1991, 351: $317-320$

38. Takada S, Gotoh Y, Hayashi S, Yoshida M, Koike K: Structural rearrangement of integrated hepatitis $B$ virus DNA as well as cellular flanking DNA is present in chronically infected hepatic tissue. J Virol 1990, 64: 822-828

39. Robinson WS, Klote L, Aoki N: Hepadna viruses in cirrhotic liver and hepatocellular carcinoma. J Med Virol 1990, 31: 18-32

40. Lee T, Finegold MJ, Shen R-F, DeMayo JL, Woo SLC, Butel JS: Hepatitis B virus transactivator $X$ protein is not tumorigenic in transgenic mice. J Virol 1990, 64: 5939-5947

41. Chisari FV, Filippi P, Buras J, McLachlan A, Popper H, Pinkert CA, Palmiter RD, Brinster RL: Structural and pathological effects of synthesis of hepaitis B virus large envelope polypeptide in transgenic mice. Proc Natl Acad Sci USA 1987, 84: 6909-6913

42. Chisari FV: New model systems for hepatitis B virus research. Lab Invest 1988, 59: 155-157

43. Chisari FV, Klopchin K, Moriyama T, Pasquinelli C, Dunsford HA, Sell S, Pinkert CA, Brinster RL, Palmiter RD: Molecular pathogenesis of hepatocellular carcinoma in hepatitis B virus transgenic mice. Cell 1989, 59: 1145-1156

44. Kozumbo WJ, Cerutti PA: Antioxidants as antitumor promotors. Basic Life Sci 1986, 39: 491-506

45. Cerutti PA: Response modification creates promotability in multistage carcinogenesis. Carcinogenesis 1988, 9: 519-526

46. Ulrich PP, Bhat RA, Kelly I, Brunctto MR, Bonino F, Vyas GN: A precore-defective mutant of hepatitis $B$ virus associated with e antigen-negative chronic liver disease. J Med Virol 1990, 32: $109-118$

47. Di Bisceglie AM, Hoofnagel JH: Hepatitis B virus replication withín the human spleen. J Clin Microbiol 1990, 28: 2850-2852

48. Haruna Y, Hayashi N, Katayama K, Yuki N, Kasahara A, Sasaki $Y$, Fusamoto $H$, Kamada T: Expression of $X$ protein and hepatitis B virus replication in chronic hepatitis. Hepatology 1991 . 13: $417-421$

49. Saito H, Morizane T. Watanabe T, Kagawa T, Matsumoto S, Iwabuchi N, Kumagai N, Tsuchimoto K. Tsuchiya M: Expression of hepatitis B surface antigen in Chang cells transfected with hepatitis B virus DNA. Keio J Med 1990, 39: 79-85

50. Choo QL, Kuo G. Weiner AJ, Overby LR, Bradley DW, Houghton $\mathrm{M}$ : Isolation of a CDNA clone derived from a bloodborne non-A non-B hepatitis genome. Science 1989, 244: 359-362

51. Saito H, Morizane T, Watanabe T, Kagawa T, Iwabuchi N, Kumagai N, Inagaki Y, Tsuchimoto K. Tsuchiya M: Establishment of a human cell line ( $\mathrm{HCC}-\mathrm{T}$ ) from a patient with hepatoma bearing no evidence of hepatitis $\mathrm{B}$ or $\mathrm{A}$ virus infection. Cancer 1989, 64: 1054-1060

52. Tremolada F, Benvegnu L, Casarin C, Pontisso P, Tagger A, Alberti A: Antibody to hepatitis $C$ virus in hepatocellular carcinoma. Lancet 1990, 335: 300-301

53. Kiyosawa K, Sodeyama T, Tanaka E, Gibo Y, Yoshizawa K, Nakano Y, Furuta S, Akahane Y, Nishioka K, Purcell RH, Alter HJ: Interrelationship of blood transfusion, non-A non-B hepatitis and hepatocellular carcinoma: analysis by detection of antibody to hepatitis C virus. Hepatology 1990, 12: 671-675

54. Saito I, Miyamura T, Ohbayashi A, Harada H, Katayama $T$, Kikuchi S, Watanabe Y, Koi S, Onji M, Ohta Y, Choo QL, Houghton M, Kuo G: Hepatitis $C$ virus infection is associated with the development of hepatocellular carcinoma. Proc Natl Acad Sci USA 1990, 87: 6547-6549

55. Vargas V, Castells L, Esteban JI: High frequency of antibodies to the hepatitis $C$ virus among patients with hepatocellular carcinoma. Ann Int Med 1990, 112: 232-233

56. Bruix J, Barrera JM, Colvet X, Ercilla G, Costa J, SanchezTapias JM, Ventura M, Vall M, Bruguera M, Bru C, Castillo R, Rodes J: Prevalence of antibodies to hepatitis $C$ virus in Spanish patients with hepatocellular carcinoma and hepatic cirrhosis. Lancet 1989, 2: 1004-1006

57. Colombo M, Kuo G, Choo QL, Donato MF. Del-Ninno E, Tommosini MA, Dioguardi N, Houghton M: Prevalence of 
antibodies to hepatitis $\mathrm{C}$ virus in Italian patients with hepatocellular carcinoma. Lancet 1990, 2: 1006-1008

58. Simonetti RG, Cottone M, Craxi A, Fagliaro L, Rapicetta $\mathbf{M}$, Chionne P, Costantino A: Prevalence of antibodies to hepatitis C virus in hepatocellular carcinoma. Lancet 1989, 2: 1338

59. Kew MC, Houghton M, Choo QL, Juo G: Hepatitis C virus antibodies in southern African blacks with hepatocellular carcinoma. Lancet 1990, 1: 873-874

60. Di Bisceglie AM, Order SE, Klein JL, Waggoner JG, Sjogren $\mathrm{MH}$, Kuo G, Houghton M, Choo QL, Hoofnagle JH: The role of chronic hepatitis in hepatocellular carcinoma in the United States. Am J Gastroenterol 1991, 86: 335-338

61. Levrero M, Tagger A, Balsano C, DeMarzio E, Avantaggiati ML, Natoli G, Diop D, Villa E, Diodati G, Alberti A: Antibodies to hepatitis $C$ virus in patients with hepatocellular carcinoma. J Hepatol 1991, 12: 60-63

62. Watanabe $\mathbf{J}$, Minegishi $\mathrm{K}$, Mitsumori, Ishifuji $\mathrm{M}$, Oguchi $\mathrm{T}$, Ueda M, Tokunaga E, Tanaka E, Kiyosawa K, Furuta S, Katayama T, Kuo G, Choo QL, Houghton M, Nishioka K: Prevalence of anti-HCV antibody in blood donors in the Tokyo area. Vox Sang 1990, 59: 86-88

63. Thaler MM, Park CK, Landers DV, Wara DW, Houghton M, Veereman-Wauters G, Sweet RL, Han JH: Vertical transmission of hepatitis C virus. Lancet 1991, 338: 17-18

64. Kuroki T, Nishiguchi S, Fukuda K, Shiomi S, Monna T, Murata R, Isshiki G, Hayashi N, Shikata T, Kobayashi K: Mother-tochild transmission of hepatitis C virus. J Infect Dis 1991, 164: $427-428$

65. Yoneyama T, Takeuchi K, Tanaka Y, Watanabe Y, Yuasa T, Harada $H$, Saito I, Ohbayashi A, Miyamura T: Detection of hepatitis $\mathrm{C}$ virus cDNA sequence by the polymerase chain reaction in hrpatocellular carcinoma tissues. Jpn J Med Sci Biol 1990, 43: 89-94

66. Kato N, Ohkoshi S, Shimotohno K: Japanese isolates of the non- $A$, non-B hepatitis viral genome show sequence variations from the original isolate in the USA. Proc Jpn Acad 1989, 65B: $219-223$

67. Kubo Y. Takeuchi K, Weiner AJ, Boonmar S, Bradley DW, Katayama T, Honghton M, Choo Q-L, Saito I, Kuo G, Miyamura $T$ : A cDNA fragment of hepatitis $C$ virus isolated from an implicated donor of post-transfusion non- $A$, non-B hepatitis in Japan. Nucleic Acids Res 1989, 17: 10367-10372

68. Takeuchi K, Boonmar S, Choo Q-L, Kubo Y, Kuo G, Katayama T, Houghton M, Harada H, Saito I, Ohbayashi A, Miyamura T: Hepatitis $\mathrm{C}$ viral cDNA clones isolated from a healthy carrier donor implicated in post-transfusion non- $A$, non- $B$ hepatitis. Gene 1990, 91: 287-291

69. Enomoto N, Takada A, Nakao T, Date T: There are two major types of hepatitis C virus in Japan. Biochem Biophys Res Commun 1990, 170: 1021-1025

70. Tsukiyama K, Kohara M, Tanaka S, Yamaguchi K, Hattori N, Toyoshima A, Nomoto A, Miki K: A second group of hepatitis $C$ virus. Virus Gene 1991, 5: 243-254

71. Kato N, Hijikata M, Sugimura T, Ootsuyama $Y$, Shimotohno $\mathrm{K}$, Nakagawa M, Ohkoshi S: Molecular cloning of the human hepatitis $C$ virus genome from Japanese patients with non-A, non-B hepatitis. Proc Natl Acad Sci USA 1990, 87: 9524-9528

72. Takamizawa A, Mori C, Onishi E, Fuke I, Andoh T, Manabe S, Yoshida I, Murakami S, Okayama H, Fujita J: Structure and organization of the hepatitis $\mathrm{C}$ virus genome isolated from human carriers. J Virol 1991, 65: 1105-1113

73. Hijikata M, Kato N, Ohkoshi S, Ootsuyama Y, Shimotohno K, Nakagawa $\mathrm{M}$ : Hypervariable regions in the putative glycoprotein of hepatitis $\mathrm{C}$ virus. Biochem Biophys Res Commun 1991, 175: 220-228

74. Weiner AJ, Brauer MJ, Crawford K, Rosenblatt J, Bonino F,
Richman KH, Saracco G, Tung J, Choo Q-L, Houghton M, $\mathrm{Han} \mathrm{JH}$ : Variable and hypervariable domains are found in the regions of $\mathrm{HCV}$ corresponding to the flavivirus envelope and NS1 proteins and the pestivirus envelope glycoproteins. Virology 1991, 180: 842-848

75. Okamoto $\mathrm{H}$ : Full-length sequence of a hepatitis $\mathrm{C}$ virus genome having poor homology to reported isolates: comparative study of 4 distinct genotypes. Virology 1992 (in press)

76. Morizane T, Watanabe $\mathrm{T}$, Tsuchimoto $\mathrm{K}$, Tsuchiya $\mathrm{M}$ : Impaired $T$ cell function and decreased natural killer activity in patients with liver cirrhosis and their significance in the development of hepatocellular carcinoma. Gastroenterol Jpn 1980, 15: 226-232

77. Nakamura T, Morizane $T$, Watanabe $\mathbf{T}$, Tsuchimoto $\mathbf{K}$, Inagaki Y, Kumagai N, Tsuchiya M: Decreased natural killer activity in patients with liver cirrhosis. Int J Cancer 1983, 32: 573-575

78. Morizane $T$, Nakamura $T$, Inagaki $Y$, Tsuchimoto $K$, Watanabe T, Saito H, Kawamura N, Satoh I, Tsuchiya M: Inhibitory effect of sera from patients with liver cirrhosis on natural killer activity. J Gastroenterol Hepatol 1986, 1: 339-346

79. Colombo M, de Franchis R, Del Ninno E, Sangiovanni A, De Fazio C, Tommasini M, Donato MF, Piva A, Di Carlo V, Dioguardi N: Hepatocellular carcinoma in Italian patients with cirrhosis. N Engl J Med 1991, 325: 675-680

80. Chung WL, Liu HW, Chang WY: Natural killer cell activity in patients with hepatocellular carcinoma relative to early development and tumor invasion. Cancer 1990, 65: 926-930

81. Winnock M, Lafon ME, Boulard A, Ferrer AM, Saric J, Dubuisson L, Bioulac Sage P, Balabaud C: Characterization of liver-associated natural killer cells in patients with liver tumors. Hepatology 1991, 13: 676-682

82. Saito $\mathrm{H}$, Morizane $\mathrm{T}$, Inagaki $\mathrm{Y}$, Kumagai $\mathrm{N}$, Watanabe $\mathrm{T}$, Nakamura T, Satoh I, Sawaguchi K, Iwabuchi N, Tsuchimoto $\mathrm{K}$, Tsuchiya M: Decrease of transplantability by the immunopotentiators, OK-432 and interleukin-2: experiments on a human hepatoma cell line in nude mice. Eur J Cancer Clin Oncol 1989 , 25: $79-89$

83. Saito H, Fukumura D, Kurose I, Suematsu M, Tada S, Kagawa T, Miura S, Morizane T, Tsuchiya M: Visualization of oxidative processes at the cellular level during neutrophil-mediated cytotoxicity against a human hepatoma cell line HCC-M. Int J Cancer 1992, 52: 1-6

84. Shimizu Y, Iwatsuki S, Herberman RB, Whiteside TL: Clone analysis of liver-infiltrating lymphocytes from human primary and metastatic liver tumors. Int J Cancer 1991, 46: 878-883

85. Kurose I, Saito H, Suematsu M, Fukumura D, Miura S, Morizane T, Tsuchiya M: Kupffer cell-mediated oxidative stress on colon cancer cell line visualized by digital imaging fluorescence microscopy. Cancer Lett 1991, 59: 201-209

86. Matsuoka M, Zang MY, Tsukamoto H: Sensitization of hepatic lipocytes by high-fat diet to stimulatory effects of Kupffer cellderived factors: implication in alcoholic liver fibrogenesis. Hepatology 1990, 11: 173-182

87. Matsuoka M, Tsukamoto H: Stimulation of hepatic lipocyte collagen production by Kupffer cell-derived transforming growth factor-betal 1: Implication for a pathogenetic role in alcoholic liver fibrosis. Hepatology 1990, 11: 599-605

88. Ito N, Kawata S, Tamura S, Takaishi K, Yabuuchi I, Matsuda I, Nishioka M, Tarui S: Expression of transforming growth factor-beta 1 in human hepatocellular carcinoma. Jpn J Cancer Res 1990, 81: 1202-1205

89. Huggett AC, Hampton LL, Ford CP, Wirch PJ, Thorgeirsson SS: Altered responsiveness of rat liver epithelial cells to transforming growth factor-beta 1 following their transformation with v-raf. Cancer Res 1990, 50: 7468-7475

90. Watanabe T, Morizane T, Tsuchimoto K, Inagaki Y, Munakata Y, Nakamura T, Kumagai N, Tsuchiya M: Establishment of a 
cell line (HCC-M) from a human hepatocellular carcinoma. Int J Cancer 1983, 32: 141-146

91. Morizane $T$, Nakamura $T$, Saito $H$, Watanabe $T$, Inagaki Y. Satoh I, Tsuchimoto K, Tsuchiya M: Transformation of NIH/3T3 cells by DNA from a human hepatoma cell line with integrated hepatitis B virus DNA. Eur J Cancer Clin Oncol 1987, 23: 163-169

92. Tada $\mathrm{M}$, Omata $\mathrm{M}$, Ohto $\mathrm{M}$ : Analysis of ras gene mutations in human hepatic malignant tumors by polymerase chain reaction and direct sequencing. Cancer Res 1990, 50: 1121-1124

93. Ogata N, Kamimura T, Asakura H: Point mutation, allelic loss and increased methylation of c-Ha-ras gene in human hepatocellular carcinoma. Hepatology 1991, 13: 31-37

94. Richards CA, Short SA, Thorgeirsson SS, Huber BE: Characterization of a transforming $\mathrm{N}$-ras gene in the human hepatocellular carcinoma cell line Hep G2: additional cvidence for the importance of c-myc and ras cooperation in hepatocarcinogenesis. Cancer Res 1990, 50: 1521-1527

95. Buetow KH, Murray JC, Israel JL, London WT, Smith M, Kew M. Blanquet V, Brechot C, Redeker A, Govindarajah S: Loss of heterozygosity suggests tumor supressor gene responsible for primary hepatocellular carcinoma. Proc Natl Acad Sci USA 1989, 86: 8852-8856

96. Wang HP, Rogler CE: Deletions in human chromosome arms $11 p$ and $13 q$ in primary hepatocellular carcinoma. Cytogenet Cell Genet $1988,48: 72-78$

97. Fujimori $M$, Tokino $T$, Hino $O$, Kitagawa $T$, Imamura $T$, Okamoto E, Mitsunobu M, Ishikawa T, Nakagama H, Harada $\mathrm{H}$ : Allelotype study of primary hepatocellular carcinoma. Cancer Res 1990, 51: 89-93

98. Bressac B, Galvin KM, Liang TJ, Isselbacher KJ, Wands JR, Ozturk M: Abnormal structure and expression of $\mathrm{p} 53$ gene in human hepatocellular carcinoma. Proc Natl Acad Sci USA 1990, 87: 1973-1977

99. Hosono S, Lec CS, Chou MJ, Yang CS, Shih CH: Molecular analysis of the p53 alleles in primary hepatocellular carcinomas and cell lines. Oncogene 1991, 6: 237-243

100. Tsuda H. Zhang WD, Shimosato Y, Yokota J, Terada M. Sugimura T, Miyamura T, Hirohashi S: Allele loss on chromosome 16 associated with progression of human hepatocellular carcinoma. Proc Natl Acad Sci USA 1990, 87: 6791-6794

101. Hsu IC, Metcalf RA, Sun T, Welsh JA, Wang NJ, Harris CC: Mutational hotspot in the p53 gene in human hepatocellular carcinomas. Nature 1991, 350: 427-428

102. Bressac B. Kew M. Wands J, Ozturk M: Selective G to T mutation of p53 gene in hepatocellular carcinoma from Southern Africa. Nature 1991, 350: 429-431

103. Simon D, Knowles BB, Weith A: Abnormalities of chromosome 1 and loss of heterozygosity on $1 p$ in primary hepatomas. Oncogene 1991, 6: 765-770

104. Zhang $W$, Hirohashi $S$, Terada $M$, Tsuda H, Sugimura $T$, Shimosato $\mathrm{Y}$, Yokota $\mathrm{J}$ : Frequent loss of heterozygosity on chromosome 16 and 4 in human hepatocellular carcinoma. Jpn J Cancer Res 1990, 81: 108-111

105. Oka H, Kurioka N, Kim K, Kanno T, Kuroki T, Mizoguchi Y Kobayashi K: Prospective study of early detection of hepatoccllular carcinoma in patients with cirrhosis. Hepatology 1990, 12: 680-687

106. Kondo S, Nishikawa M, Takami S, Fukuzaki T, Kurokawa M. Ohi M. Shimomukai H, Matsuda Y, Kuroki K: Diagnostic value of lipiodol injection in focal nodular hyperplasia of the liver. Am J Gastroenterol 1991, 86: 779-781

107. Hirai K, Aoki Y, Majima Y, Abe H, Nakashima O, Kojiro M, Tanikawa K: Magnetic resonance imaging of small hepatocellular carcinoma. Am J Gastroenterol 1991, 86: 205-209

108. Gandon $\mathrm{Y}$, Heautot JF, Brunet $\mathrm{F}$, Guyader D, Deugnier $\mathrm{Y}$,
Carsin M: Superparamagnetic iron oxide: Clinical time-response study. Eur J Radiol 1990, 12: 195-200

109. Nakao A, Suzuki Y, Isshiki K, Kimura Y, Takeda S, Kishimoto W, Nonami T, Harada A. Takagi H: Clinical cvaluation of plasma abnormal prothrombin (des-gamma-carboxy prothrombin) in hepatobiliary malignancics and other diseases. Am J Gastroenterol 1991, 86: 62-66

110. Du MQ, Hutchinson WL, Johnson FJ, Williams R: Differential alpha-fetoprotein lectin binding in hepatocellular carcinoma. Diagnostic utility at low serum levels. Cancer 1991, 67: 476-480

111. Marotta F, Chui DH, Safran P, Zhang SC: Serum alpha-Lfucosidase. A more sensitive marker for hepatocellular carcinoma? Dig Dis Sci 1991, 36: 993-997

112. Aoyagi Y, Suzuki Y, Igarashi K, Saitoh A, Oguro M, Yokota T, Mori S, Nomoto M, Isemura M, Asakura H: The usefulness of simultaneous determinations of glucosaminylation and fucosylation indices of alpha-fetoprotein in the differential diagnosis of neoplastic diseases of the liver. Cancer 1991, 67: 2390-2394

113. Grieco A, De Stefano V, Cassano A, Ciabattoni A, Garufi C, Astone A, Leone G, Barone C: Hepatocarcinoma in cirrhosis. Is antithrombin III a neoplastic marker? Dig Dis Sci 1991, 36: $990-992$

114. Tomiya T, Fujiwara K: Plasma thrombin-antithrombin II complexes in the diagnosis of primary hepatocellular carcinoma complicating liver cirrhosis. Cancer 1991, 67: 481-485

115. Leandro G, Zizzari S, Piccoli A, Manghisi OG: The serum tissue polypeptide antigen in the detection of hepatocellular carcinoma in cirrhotic patients. Hepatogastroenterol 1990, 37: $449-451$

116. Tanaka S, Kitamura T, Nakanishi K, Okuda S, Kojima J Fujimoto I: Recent advances in ultrasonographic diagnosis of hepatocellular carcinoma. Cancer 1989, 63: 1313-1317

117. Sbolli G, Fornari F, Civardi G, Di Stasi M, Cavanna L, Buscarini $\mathrm{E}$, Buscarini $\mathrm{L}$ : Roles of ultrasound guided fine needle aspiration biopsy in the diagnosis of hepatocellular carcinoma. Gut 1990. 31: $1303-1305$

118. Cohen MB, Haber MM, Holly EA, Ahn DK. Bottles K, Stoloff A: Cytologic criteria to distinguish hepatocellular carcinoma from nonneoplastic liver. Am J Clin Pathol 1991, 95; 125-130

119. Kung ITM, Cahn SK. Fung KH: Fine-needle aspiration in hepatocellular carcifoma. Cancer 1991, 67:673-680

120. Komatsu T, Kondo Y, Yamamoto Y, Isono K: Hepatocellular carcinoma presenting well differentiated, normotrabecular patterns in peripheral or metastatic loci. Analysis of 103 resected cases. Acta Pathol Jpn 1990, 40: 887-893

121. Sakamoto M. Hirohashi S, Shimosato Y: Early stages of multistep hepatocarcinogenesis: adenomatous hyperplasia and early hepatocellular carcinoma. Human Pathol 1991, 22: 172-178

122. Kanai T. Hirohashi S, Upton MP, Noguchi M. Kishi K, Makuuchi $M$, Yamasaki S, Hasegawa $H$, Takayasu $K$, Moriyama $N$, Shimosato Y: Pathology of small hepatocellular carcinoma. A proposal for a new gross classification. Cancer 1987, 60: $810-819$

123. Yuki K,Hirohashi S, Sakamoto M, Kanai T, Shimosato Y: Growth and spread of hepatocellular carcinoma. A review of 240 consecutive autopsy cases. Cancer 1990, 66: 2174-2179

124. Takayama T, Makuuchi M, Hirohashi S, Sakamoto M, Okazaki N, Takayasu K. Kosuge T, Motoo Y, Yamazaki S, Hasegawa $\mathbf{H}$ : Malignant transformation of adenomatous hyperplasia to heaptocellular carcinoma. Lancet 1990, 336: 1150-1153

125. Rapaccini GL, Pompili M, Caturelli E, Anti M, Aliotta A. Cedrone A, Amadei E. Gattagliano A. Squillante MM. Rabitti C. Gambassi G: Focal ultra sound lesions in liver cirrhosis diagnosed as regenerating nodules by finc-needle biopsy. Dig Dis Sci 1990, 35: 422-427

126. Okazaki N, Kosuge T, Takayama S, Okada S, Yoshino K, 
Takayasu K, Moriyama N, Sakamoto M, Hirohashi S: Accelated tumor growth and changes in images concomitant with vascularization in a patient with hepatocellular carcinoma. HepatoGastroenterol 1991, 38: 160-164

127. Yoshimatsu S, Inoue $\mathrm{Y}$, Ibukuro K, Suzuki S: Hypovascular hepatocellular carcinoma undetected at angiography and CT with iodized oil. Radiology 1989, 171: 343-347

128. Sonoda T, Shirabe K, Takenaka K, Kanematsu T, Yasumori K, Sugimachi K: Angiographically undetected small hepatocellular carcinoma: clinicopathological characteristics, follow-up and treatment. Hepatology 1989, 10: 1003-1007

129. Matsui D, Kadaya M, Kameyama T, Yoshikawa J, Takashima $T$, Nakanuma $Y$, Unoura $M$, Kobayashi $K$, Izumi $K$, Ida $M$, Kitagawa K: Benign and malignant nodules in cirrhotic livers: Distinction based on blood supply. Radiology 1991, 178: 493-497

130. Matsui O, Kadoya M, Suzuki M, Inoue K, Itoh H, Ida M, Takashima T: Dynamic squential computed tomography during arterial portography in the detection of hepatic neoplasms. Radiology 1983, 146: 721-727

131. Nelson RC,. Chezmar JL, Sugarbaker FH, Bernardino ME: Hepatic tumors: comparison of $\mathrm{CT}$ durign arterial portography, delayed CT, and MR imaging for preoperative evaluation. Radiology 1989, 172: 27-34

132. Heiken JP, Weyman PJ, Lee JK, Balfe DM, Picus D, Brunt EM, Flye MW: Detection of focal hepatic masses: prospective evaluation with CT, delayed CT, CT during arterial protography, and MR imaging. Radiology 1989, 171: 47-51

133. Merine D, Takayasu K, Wakao F: Detection of hepatocellular carcinoma: comparison of CT during arterial portography with CT-after intraarterial injection of iodized oil. Radiology 1990 , 175: $707-710$

134. Novell R, Dusheiko G, Hilson A, Dick R, Begent K, Hobbs K: Lipiodol computed tomography for small hepatocellular carcinoams. Lancet 1991, 337: 729

135. Saito $\mathrm{H}$, Morizane $\mathrm{T}$, Watanabe $\mathrm{T}$, Kagawa $\mathrm{T}$, Miyaguchi $\mathbf{S}$, Kumagai N, Tsuchiya M: Differentiating effect of sodium butyrate on human hepatoma cell lines PLC/PRF/5, HCC-M and HCC-T. Int J Cancer 1991, 48: 291-296

136. Morizane T, Kagawa T, Saito H, Guevara FM, Miyaguchi S, Tsuchiya M: Treatment of chronic hepatitis C with weekly administration of interferon- $\alpha$. Gastroenterol Jpn 1991, 26 (Suppl 3): 254-255 